\title{
O PERCURSO DA MEMÓRIA: LINGUAGEM E DISCURSO NA NARRATIVA BÍBLICA
}

\section{Cláudia Andréa Prata Ferreira*}

Resumo: Interpretação das fontes bíblica e talmúdica na Tradição Judaica. Compreendemos os textos bíblico e talmúdico como sendo um projeto de construção da memória. Essa memória, construída literariamente a partir de uma tradição oral e escrita, evidencia uma relação singular entre o humano e o divino e procura legitimar em seu discurso a idéia de uma Religião e Tradição do Livro. Essa memória constitui, então, o elemento essencial no projeto de construção da identidade individual ou coletiva do Povo do Livro (em hebraico, Am Ha'Sefer). Estabelecemos a relação memória e religião tendo como elemento central a palavra hebraica zikaron "lembrança, memória". A originalidade do presente projeto é elencar um conjunto de elementos nos quais se articulam a construção e formação da identidade e memória no Judaísmo tendo como referencial as fontes judaicas, em particular, as produzidas em língua hebraica. Memória, Linguagem e discurso na narrativa, interpretando o caso específico da narrativa hebraica bíblica e a narrativa talmúdica: privilegiamos as fontes bíblica e talmúdica, pilares da fé judaica.

Palavras-chave: Judaísmo, memória, identidade, linguagem, narrativa

Os patriarcas e matriarcas têm, como elemento comum, um pacto com Deus, no qual se estabelece um compromisso mútuo, que se ratifica a cada geração na transmissão de valores e pela circuncisão. De acordo com o texto bíblico, Avraham, o primeiro hebreu, abandona o lar na Mesopotâmia em cumprimento à ordem divina, na direção de um novo destino (Gn 12, 1-2). A circuncisão é a formalização do pacto entre Avraham e Deus por meio de um sinal físico (Gn 17, 10-11). O pacto se renova com o filho de Avraham, Isaac $(\mathrm{Gn} 26,24)$ e por sua vez, a promessa divina se repete também com Jacó, filho de Isaac e neto de Avraham (Gn 28, 13-15).

* Professora Adjunta do Departamento de Letras Orientais e Eslavas, Faculdade de Letras - UFRJ. Doutora em Ciência da Literatura - Poética (FL/UFRJ). 
${ }^{1}$ E disse o Eterno a Abrão (Avram): "Anda de tua terra e da tua parentela e da casa de teu pai, para a terra que te mostrarei. ${ }^{2} E$ farei de ti uma grande nação, e abençoarte-ei, e engrandecerei teu nome, e serás uma bênção" (TORÁ, Gn 12, 1-2 p.29.).

${ }^{10}$ Esta é a Minha aliança, que guardareis entre Mim e vós (os de agora,) e a tua semente depois de ti: Será circuncidado em vós todo varão. ${ }^{11} \mathrm{E}$ circundareis a carne de vosso prepúcio, e será por sinal de aliança entre Mim e vós (TORÁ, Gn 17, 10-11 p.39.).

${ }^{13} E$ eis que o Eterno estava sobre ela, e dizia: "Eu sou o Eterno, Deus de Abraão, teu pai, e Deus de Isaac; a terra em que tu jazes sobre ela, a ti a darei e à tua semente. ${ }^{14} \mathrm{E}$ será a tua semente como o pó da terra, e te fortalecerás, ao oeste, ao leste, ao norte e ao sul; e por ti serão benditas todas as famílias da terra, e por tua posteridade. ${ }^{15} \mathrm{E}$ eis que Eu estou contigo, e te guardarei por onde quer que fores, e te farei voltar a esta terra; porque não te abandonarei até que Eu faça o que falei por ti" (TORÁ, Gn 28 13-15 p.79.).

$\mathrm{Na}$ palavra hebraica Israel temos as iniciais dos nomes dos patriarcas e das matriarcas, a família original que dá origem a Israel. Na passagem de Gênesis 32, 29, a etimologia sugere o significado de Israel: "E disse: Não, Jacob não será mais teu nome, senão Israel, pois lutaste com (o anjo de) Deus e com homens e venceste" (TORÁ, Gn 32, 29 p.95.). Temos literalmente sara "ele lutou"- ki saríta ím Elohim "porque lutaste com Deus" e el "Deus". O verbo sara tem o sentido de "lutar", "combater" e pede o uso das preposições el "para", et "indicativo de objeto direto definido - sem equivalência na língua portuguesa" e im "com". A maior parte dos dicionários prefere indicar como significado e etimologia incertos e fornecem apenas o sentido de nome masculino e gentílico. Na palavra Israel encontramos o semen, a semente do significado para a realização de um pacto entre Deus e Israel, que manterá a memória e identidade de um grupo através dos tempos e definirá as regras de sua relação com o divino.

Mencionamos anteriormente, que as iniciais dos nomes dos Patriarcas (Abraão, Isaac e Jacó) e das Matriarcas (Sara, Rebeca, Lia e Raquel) formam a palavra ISRAEL. O acrograma acima é perfeito 
com os nomes em hebraico. Em português, tem-se uma idéia aproximada.

A família original se transferiu para a terra do Egito devido a um período de seca em Canaã. Inicialmente, os descendentes de Avraham foram beneficiados pelo posto ocupado por José, filho de Jacó na estrutura política egípcia. No livro de Êxodo, encontramos o relato de que em determinado momento da história egípcia, um novo rei que não conhecera José escravizou os filhos de Israel, que ali permaneceram na condiçãc de escravos durante um período de aproximadamente quatrocentos anos (Ex 1).

Esse episódio constitui motivo de recordação e reflexão que marcam a festividade de Pessach, a Páscoa Judaica, que celebra a libertação do cativeiro egípcio. Esse episódio marca não somente a intervenção divina, agindo histórica e concretamente em benefício dos descendentes dos patriarcas, com os quais tinha um pacto, mas reafirma esse pacto com a revelação do que posteriormente conhecemos como Torá (Pentateuco). Esse pacto cria o judaísmo propriamente dito como uma religião com seu texto de referência, estatutos, normas de conduta de vida revelados coletivamente aos descendestes dos patriarcas, os filhos de Israel, que trazem em seu nome a marca do pacto realizado com seus antepassados. Essa marca continuará no nome Israel, mas terá um novo alcance com o que foi revelado no Monte Sinai.

A Torá estabelece o terceiro elemento do pacto entre Deus e os patriarcas. Se anteriormente a relação pactual era terra-povo, a partir de Moisés e o pacto sinaítico, o pacto se renova com uma tríplice condição: terra-povo-Torá. Terra, povo e Torá são os elementos interdependentes que formam um tripé, que sustentam o judaísmo.

A história do Exxodo está entrelaçada de insights, que surgem quando desbastamos as camadas superficiais do sentido da texto bíblico. O lugar determinado para o acampamento dos bnei Israel (Filhos de Israel) frente ao Mar de Junco ("Mar Vermelho" em um equívoco de tradução) é pi há-chirot "boca da liberdade" (Ex 14, 9). O mar divide o reino egípcio da região do deserto. Em hebraico, o termo usado para "deserto" é midbar, que significa literalmente "de uma coisa (ou palavra)". A preposição $m i$ afixada à palavra nos transmite o sentido de origem, procedência. O deserto funciona como uma 
transição para a realização de um novo pacto entre Deus e o homem. O mar é a entrada para o deserto. O mar tem o nome de suf "junco" e pode ser lido como sof "fim" ou saf "entrada". Pois a raiz hebraica $s f$ (sem a vocalização) nos permite fazer esse jogo de significados. Considerando as possibilidades de significados da raiz hebraica, compreendemos o mar como fim ou fronteira de um mundo e a entrada para outro mundo. Para realizar o pacto, torna-se necessário sair do Egito, cuja palavra em hebraico Mitsráyim tem o sentido de "limitações", realizar a travessia pelo mar e seguir em direção ao deserto. Atravessar o suf (Mar de Junco) é colocar um sof nos acontecimentos anteriores e se preparar para um experiência única tanto a nível individual quanto coletivo na história judaica. A verdadeira divisão do mar pode ser encontrada na passagem de $\hat{E x o d o}$ 14, 21: "E estendeu Moisés sua mão sobre o mar e levou o Eterno o mar, com um forte vento oriental, toda a noite, e fez do mar terra seca, e foram divididas as águas" (TORÁ, Ex 14, 21 p.196). A jornada espiritual presente na essência de todas as religiões se manifesta no judaísmo na história do $\hat{E x o d o . ~ E s t a ~ j o r n a d a ~ e ́ ~ a ~ h i s t o ́ r i a ~ c e n t r a l ~ d o ~}$ texto bíblico e presença constante na liturgia judaica onde é descrita como um memorial do êxodo do Egito. O condutor do povo nessa travessia rumo à jornada espiritual é Moisés, nome de origem egípcia Mes-es-su "filho de...", "gerado por ...", nome que aparece quase exclusivamente seguido pelo nome de alguma divindade egípcia teria provavelmente um nome mais longo. A forma breve do nome, que passou a ser conhecida por todos como Moisés, deve-se provavelmente, à recusa por parte de Moisés de ter o nome de um ídolo egípcio no nome, sendo ele o líder espiritual de um povo que venera um Deus único. Por sua vez, na fonte bíblica, o nome Moisés aparece derivado do verbo hebraico mashá, que significa "tirar", donde temos que Moisés poderia significar "aquele que é tirado" ou seguindo o rigor gramatical, "aquele que tira": "...e chamou seu nome Moisés [Moshé] e disse: Porque das águas o tirei." (TORÁ, Ex 2, 10 p.156).

Diferentemente de uma íntima revelação de Deus a Abraão, que resulta numa aliança que passa de pai para filho, a Revelação no Sinai e a aliança dela resultante, foram testemunhadas coletivamente pelas pessoas que deixaram o cativeiro egípcio. O pacto agora foi feito num espaço público e dirigido à coletividade tendo Moisés como parceiro humano de Deus. 
O ato de lembrar no judaísmo torna-se imperativo, pois é ele que garante através da perpetuação da memória que os acontecimentos fundamentais e constitutivos para a formação desse grupo (o judaico) e do pacto com Deus não se percam na memória dos filhos de Israel. Não se trata mais de um grupo de famílias divididas pelas origens das tribos ou de uma revelação individual que passa de pai para filho por fidelidade ao clã, ao patriarca. A lembrança da saída do Egito é fundamental para a compreensão do nascimento do povo e da própria religião. A saída do Egito marca o início do povo judeu como um grupo organizado e regido por suas próprias leis, reveladas ao povo por Moisés, sete semanas após a saída do cativeiro egípcio. Podemos inferir que muitas das leis presentes no texto bíblico tenham sido criadas sob o impacto do efeito do cativeiro egípcio sobre o povo judaico. Encontramos um número expressivo de leis que tratam de questões sociais que se referem ao pobre, ao estrangeiro, aos órfãos e viúvas, trabalhadores, atitudes de tolerância e benevolência, nos quais a lembrança do cativeiro egípcio é freqüentemente mencionada através de um leitmotiv que funciona como um imperativo de lembrança "E lembrarás que servo foste na terra do Egito" (Dt 5, 15) e que perpassa o texto bíblico em diversas passagens. Essa lembrança justifica todas as orientações da legislação social com o intuito de estabelecer procedimentos justos para com os menos favorecidos.

A memória judaica não se encontra restrita à narrativa. Manter a memória restrita ao âmbito da narrativa poderia fazer com que a mesma ficasse paralisada no tempo e sem sentido para as gerações futuras. A memória judaica ganha sentido e realidade somente quando, através da repetição do ritual, o tempo histórico é destruído e podemos experenciar de novo o tempo verdadeiro das origens, o tempo originário. Na festividade de Pessach reproduzimos a cada ano a experiência da saída do cativeiro egípcio, a libertação, em que cada indivíduo judeu refaz a sua história como se ele próprio tivesse saído do Egito. O relato dessa saída é vivencial e se destina a todos, não se pretende que as pessoas tenham uma aquisição intelectual do fato, ao contrário, o objetivo é a repetição simbólica da experiência original, que auxilia a compreensão de um fato passado e simultaneamente um fato presente na vida de cada um que revive essa experiência. 
A raiz hebraica para designar memória é composta pelas letras $z k r(z c h r)$. Essa raiz se faz presente na literatura e na liturgia para nos recordar o dever da lembrança. ${ }^{1}$

A memória judaica foi essencialmente preservada pela transmissão oral e pela tradição como um mandamento coletivo conforme observamos nas passagens do livro de Deuteronômio.

1 A liturgia judaica costuma se referir a Rosh Hashaná (o ano novo judaico) como o iom há-zikaron "Dia da Recordação", período de lembrança de Deus e do homem e conceito central durante o período de Iamim Noraim "Dias intensos", período entre Rosh Hashaná e Iom Kipur "Dia do Perdão". Há uma parte litúrgica conhecida como zichronot "Recordações" que compreende os versículos bíblicos que mencionam as lembranças de Deus daqueles que não o esquecem.

Estrutura da uma parte litúrgica conhecida como zichronot "Recordações":

01)Ata zocher (Tu recordas os feitos do mundo) - Oração introdutória a zichronot que enfatiza a imagem de que Deus nestes dias tem diante de $\mathrm{Si}$ um registro de todos os atos e intenções de cada indivíduo. Deus tem a lembrança de quem temos sido.

b) Os dez versos contêm a raiz zkr (zchr) "lembrança".

Eloheinu ve-Elohei Avoteinu (Nosso Deus e Deus de nossos antepassados). Bênção que introduz o toque do shofar e que solicita de acordo com o tema deste segmento: zochrenu be-zikaron lefanecha (Lembra-nos como uma boa recordação diante de Ti).

c) Toques do shofar.

* shofar - pequena trombeta feita com o chifre do carneiro que se toca sobretudo nas festividades de Rosh Hashaná e Iom Kipur "Dia do Perdão".

No judaísmo pós-bíblico, a raiz zkr (zchr) é usada pelos rabinos para mostrar respeito a Deus. Os rabinos se referem freqüentemente à Quarta letra do nome inefável de Deus como azkará "recordação", vem da raiz $z k r(z c h r)$, palavra aramaica também usada para uma cerimônia em memória dos mortos (geralmente realizada no $30^{\circ}$ dia após o falecimento). Temos ainda o serviço de Izkor "que Ele se lembre", palavra inicial da oração realizada em memória dos mortos no serviço de Iom Kipur e em tempos mais recentes, também recitado nas festividades de Pessach, Shavuot "Semanas" e Sucot "Cabanas". 
E lembrarás que servo foste na terra do Egito, e que de lá te tirou o Eterno, teu Deus, com mão forte e com braço estendido (TORÁ, Dt 5, 15 p.522).

"Quando te perguntar teu filho amanhã, dizendo: Que significam os testemunhos, os estatutos e os juízos que o Eterno, nosso Deus, vos ordenou? E dirás a teu filho: Escravos fomos do Faraó no Egito, e nos tirou o Eterno do Egito com mão forte; e nos fez o Eterno sinais e milagres grandes e maus contra o Egito, contra o Faraó e contra toda a sua casa, ante os nossos olhos. E a nós, nos tirou de lá para nos trazer e para nos dar a terra que jurou a nossos pais. E ordenou-nos o Eterno observar todos estes estatutos, e que temêssemos ao Eterno nosso Deus, para que seja bem para nós, todos os dias, e para deixarnos viver, como até hoje" (TORÁ, Dt 6, 20-24 p.525526).

${ }^{17}$ Recorda-te do que te fez Amalec no caminho quando saíeis do Egito, ${ }^{18}$ que te encontrou pelo caminho e feriu todos os desfalecidos que ficavam atrás de ti, e tu estavas sedento e cansado, e Amalec não temeu a Deus. ${ }^{19}$ Quando, pois, o Eterno, teu Deus, te der descanso de todos os teus inimigos em redor, na terra que o Eterno, teu Deus, te está dando por herança para possuí-la, apagarás a memória de Amalec de debaixo dos céus; não te esquecerás (TORÁ, Dt 25, 17-19 p.577, te ordena cumprir estes estatutos e os juízos; e os guardarás e os observarás com todo teu coração e com toda tua alma (TORÁ, Dt 26, 16 p.580).

Lembra-te dos dias da antiguiidade, atentai para os anos das gerações sucessivas; pergunta a teu pai e ele te informará; aos teus anciãos e eles te dirão (TORÁ, Dt 32, 7 p.600).

O conteúdo da memória judaica foi primeiramente a saga coletiva tal como registrada na fonte bíblica e posteriormente, em coletividade, os rituais rememorando esses acontecimentos. O significado central do passado bíblico é o pacto, o pacto da memória, a garantia de que Israel seguirá através da história o plano divino. A memória judaica é essencialmente um reconhecimento de Deus, do pacto e de sua revelação através da Torá, memória fundadora da 
identidade judaica. A lealdade para com Deus, parte constitutiva do pacto da memória, que tirou seu povo do cativeiro egípcio, se torna elemento constitutivo de Israel. A Torá, além de ser dom divino, aparece como tarefa do povo, pois o povo vivenciando seus ensinamentos preserva o sentido da existência e faz com que estes ensinamentos sejam um zikaron "lembrança", "memória" do que foi, é e será.

No texto bíblico, a lembrança é fundamental. O verbo hebraico lizkór "lembrar" aparece em várias conjugações, tendo como tema Israel ou Deus, uma vez que ambos estão ligados pelo Pacto da Memória.

No livro de Gênesis, encontramos o mundo primevo de tempo-sonho dos arquétipos, representado pela história do paraíso. O tempo histórico tornou-se real após a saída de Adão e Eva do Jardim do Éden. O homem é lançado na história contra a sua vontade. No pensamento hebraísta, o homem veio para afirmar a sua existência histórica e, gradualmente, descobre que Deus o revela a ele próprio durante o decurso da história. Os rituais e as festas de Israel Antigo não são mais repetições de arquétipos míticos destinados a acabar com o tempo histórico. Na evocação do passado não se trata mais do passado primevo, mas do passado histórico, no qual ocorrem os momentos marcantes da histórica de Israel. A manifestação religiosa bíblica está impregnada de história e não pode ser concebida apartada dela. Deus só se torna conhecido quando Ele se revela para a coletividade que saiu do Egito, mais que isso, quando Ele se revela historicamente como o agente que possibilitou a saída dos hebreus do cativeiro egípcio: "Vai-te, junta os anciões de Israel e dize-lhes: O Eterno Deus de vossos pais apareceu a mim; o Deus de Abraão, Isaac є Jacob, dizendo: Tenho-vos visitado e o que vos está sendo feito no Egito" (TORÁ, Ex 3, 16 p.159). Quando Deus se apresenta no Sinai para todo o povo, não temos uma descrição de sua essência ou atributos, mas o que ele fez por esse povo: "Eu sou o Eterno, teu Deus, que te tirei da terra do Egito, da casa dos escravos" (TORÁ, Ex 20,2 p.214). O povo sabe o que é Deus, devido àquilo que Ele fez na história. Dessa forma, a memória tornou-se o elemento fundamental para sua fé e, por extensão, para sua própria existência. A lembrança é um imperativo religioso direcionado a todo o povo.

${ }^{17}$ Recorda-te do que te fez. Amalec no caminho quando saíeis do Egito, ${ }^{18}$ que te encontrou pelo caminho e feriu 
todos os desfalecidos que ficavam atrás de ti, e tu estavas sedento e cansado, e Amalec não temeu a Deus (TORÁ, Dt 25, 17-18 p.577).

Lembra-te dos dias da antigüidade, atentai para os anos das gerações sucessivas; pergunta a teu pai e ele te informará; aos teus anciãos e eles te dirão (TORÁ, Dt 32,7 p.600).

Jacó, lembra-te disso, Israel: tu és meu servo, eu te modelei como servo para mim; tu, Israel, não me decepcionarás (TEB, Is 44, 21 p.484).

Povo meu, lembra-te do que tramava Balaq, rei de Moab, do que lhe respondeu Bileâm, filho de Beor, na passagem de Shitim a Guilgal, e então reconhecerás as vitórias do Senhor (TEB, Mq 6, 7 p.667).

Embora o ato de lembrar seja imperativo para a existência e compreensão de Israel, devemos destacar que não a história, como supomos, mas apenas o tempo mítico se repete. A travessia do Mar Vermelho, enquanto tempo histórico só pode ser atravessado pelo povo uma única vez, mas a lembrança desse acontecimento, nos permite realizar várias travessias através dos tempos, e realizando essa travessia pela narrativa podemos vivenciar um fato passado no tempo presente tão somente tentando extrair-lhe o sentido da nossa própria existência. O tempo histórico pode ser único e como tal, acontece uma única vez, mas o pacto entre Deus e Israel, o Pacto da Memória continua eternamente: "E não somente convosco eu faço esta aliança e este juramento, mas com aquele que hoje está aqui presente diante do Eterno, nosso Deus, e com aquele que hoje não está aqui conosco" (TORÁ, Dt 29, 13-14 p.590).

Encontramos mais uma passagem significativa entre memória e tempo:

${ }^{6}$ Quando amanhã vossos filhos vos perguntarem: "Que significam essas pedras para nós?", ${ }^{7}$ dir-lhes-eis: "É que as águas do Jordão foram cortadas diante da arca da aliança do Senhor, quando ela passou pelo Jordão! As águas do Jordão foram cortadas e essas pedras servirão de memorial para os filhos de Israel para sempre" (TEB, Js $4,6-7$ p.250). 
Não a pedra em si, mas sim a memória transmitida pelos antepassados é decisiva, se a memória contida na pedra tiver que ser invocada a reviver o acontecimento para as gerações futuras. Não podemos retornar ao Sinai, mas podemos participar dele através da memória de que a pedra é portadora.

$\mathrm{O}$ apelo que encontramos no texto bíblico para lembrança e memória tem pouca relação com uma curiosidade sobre o passado. Os bnei Israel "Filhos de Israel" são instruídos apenas para ser um reino de sacerdotes e um povo sagrado e não um povo de historiadores. Israel não tem a obrigação de recordar todo o passado, mas sim de parte dele, dos atos de intervenção divina na história, e as respostas do homem, negativas ou positivas.

${ }^{10} \mathrm{E}$ quando te levar o Eterno, teu Deus, à terra que jurou a teus pais, a Abraão, a Isaac e a Jacob, e de te der cidades grandes e boas que não edificaste; ${ }^{11} \mathrm{e}$ casas cheias de todas as boas coisas que tu não encheste; e poços cavados que não cavaste; vinhas e oliveiras que não plantaste; e comeres e te fartares, ${ }^{12}$ guarda-te de não esquecer ao Eterno, que te tirou da terra do Egito, da casa dos escravos (TORÁ, Dt 6, 10-12 p.525).

${ }^{11}$ Guarda-te que não te esqueças do Eterno, teu Deus, deixando de observar os Seus mandamentos, os Seus juízos e os Seus estatutos, que te ordeno hoje, ${ }^{12}$ para não suceder que, depois de teres comido e estares farto, depois de teres edificado boas casas e habitado nelas, ${ }^{13} \mathrm{e}$ teu gado e teu rebanho se terem multiplicado, e tua prata e o teu ouro se terem aumentado, e tudo que possuíres se ter multiplicado, ${ }^{14}$ por isso tudo, se orgulhe o teu cotação e te esqueças do Eterno, teu Deus, Quem te fez sair da terra do Egito, da casa dos escravos; ${ }^{15}$ Quem te conduziu pelo deserto grande e temível, em que há cobras, serpentes abrasadoras e escorpiões, lugar árido onde não há água; Quem fez sair para ti água da rocha forte; ${ }^{16}$ Quem no deserto te fez comer Maná, que teus pais não conheceram; para te afligir e para te provar, para te fazer bem afinal. ${ }^{17}$ Quiçá dirás no teu coração: "A minha força e a fortaleza da minha mão conseguiram estes bens!" ${ }^{18}$ Mas, antes te lembrarás do Eterno, teu Deus, porque é Ele quem te dá força para conseguires riqueza, a fim de 
confirmar Sua aliança, que jurou a teus pais, como o faz hoje (TORÁ, Dt 8, 11-18 p.530-531).

A memória fluiu basicamente através de dois canais, o ritual e a narrativa. Mesmo quando preservando os seus laços orgânicos com os ciclos naturais do ano agrícola - exemplo da festividade de Pessach, a Páscoa judaica, que cai no início da primavera - as grandes peregrinações e as festividades da Páscoa e do Tabernáculo foram transformadas em comemorações do Êxodo do Egito e do período de estadia no deserto. Temos, no livro de Deuteronômio, um exemplo de junção entre ritual e narrativa a serviço da memória, por ocasião da cerimônia dos primeiros frutos, onde o celebrante traz seus frutos para o santuário e deve fazer a seguinte declaração, que encontramos em Deuteronômio 26, 5-10:

${ }^{5}$ E falarás em voz alta e dirás diante do Eterno, teu Deus: "Labão [Laván], o arameu, quis fazer perecer o meu pai, e este desceu ao Egito e peregrinou ali com pouca gente, e ali veio a ser nação grande, forte e numerosa. ${ }^{6} \mathrm{E}$ nos trataram mal os egípcios, nos afligiram e nos impuseram duros trabalhos. ${ }^{7} \mathrm{E}$ clamamos ao Eterno, Deus de nossos pais, e ouviu o Eterno nossa voz, e viu nossa aflição, nossa fadiga e nossa opressão; ${ }^{8} \mathrm{e}$ tirou-nos o Eterno do Egito com mão forte, com braço estendido e com grande temor, e com sinais e com milagres. ${ }^{9} \mathrm{E}$ trouxe-nos a este lugar e nos deu esta terra, terra que emana leite e mel. ${ }^{10}$ Eis que agora eu trouxe as primícias do fruto da terra que me deste, $\sigma$ Eterno!" E pousarás o cesto diante do Eterno, teu Deus, e te prostrarás diante do Eterno, teu Deus (TORÁ, Dt 26, 5-10 p.578-579).

A passagem acima contém uma história sintetizada nos seus aspectos essenciais do que deve ser lembrado sob uma forma ritualizada. Encontramos as origens patriarcais na Mesopotâmia, o surgimento da nação hebraica, a escravidão no Egito e a libertação, a conquista da terra prometida e perpassando todo esse painel histórico, a consciência de Deus como o senhor da história.

A necessidade e o dever da lembrança não ficaram restritos ao corpus bíblico do Pentateuco, mas estendeu-se, igualmente, à narrativa histórica de livros como Josué, Samuel I e II, Reis I e II, Crônicas I e II, além da produção literária profética. A história bíblica 
tem em sua essência uma narrativa dos atos divinos, mas está igualmente repleta das ações humanas e dos feitos de Israel e das nações. Admite-se que a narrativa histórica de Israel Antigo tem suas raízes na crença de que a história era uma teofania, e que sendo assim, basicamente os acontecimentos deveriam ser interpretados sob a ótica dessa fé.

A interpretação do texto bíblico já aparece desde a época anterior aos anos 70 E.C., como atividade religiosa por excelência e desemboca numa intensa atividade exegética na literatura rabínica. Essa atividade rabínica de interpretar o texto bíblico e criar uma hermenêutica elaborada tem como fonte de inspiração a própria fonte bíblica. O sentido de Midrash como um processo de "interpretação e exposição" já estaria presente na própria Bíblia numa espécie de processo de Bíblia que gera Bíblia ${ }^{2}$. A Bíblia é ela própria um texto interpretado, os profetas interpretam a Torá (Pentateuco) e fonte de toda uma tradição de interpretação, a fonte talmúdica. De acordo com essa perspectiva, a Bíblia é o substrato de um longo processo exegético no qual os livros do corpus bíblico interpretam-se uns aos outros e que a Bíblia é a primeira intérprete de si mesma. A hermenêutica rabínica que fundamentalmente é o comentário da Bíblia e posteriormente, o comentário do comentário, dessa forma, dá continuidade a esse processo interpretativo que já estaria presente na Bíblia. A interpretação na tradição judaica é caracteristicamente um intenso processo de procura do sentido da palavra divina e uma forma de perpetuar a memória dessa relação entre Deus e Israel através dos tempos. Dessa maneira, a necessidade em compreender o sentido da existência tem como resposta o Pacto da Memória realizado entre Deus e Israel. A memória acaba por gerar o ato interpretativo como um ato de procura de sentido. Longe de esgotarmos essa atitude midráshica no texto bíblico, que inspirou a literatura rabínica, trazemos alguns casos para ilustrar o que comentamos acima.

Destacamos o papel dos profetas na atualização e interpretação das tradições de Israel. Podemos observar como o profeta Jeremias usa a legislação do divórcio para contrastar a relação entre Deus e o povo.

2 TREBOLLE BARRERA, 1995, p.513-520. 


\section{Deuteronômio 24, 1-4}

${ }^{1}$ Quando um homem tomar uma mulher e se casar com ela, e se ela não for agradável aos seus olhos, por haver achado nela alguma coisa indecente, escrever-lhe-á uma carta de divórcio, e a dará em sua mão e a despedirá de sua casa. ${ }^{2} E$ tendo ela saído da sua casa, poderá ir e tornar-se mulher de outro homem. ${ }^{3} \mathrm{E}$ se este último homem dela se aborrecer e lhe escrever uma carta de divórcio, a der na sua mão e a despedir de sua casa, ou se este último homem que a tomou para si por mulher vier a morrer, ${ }^{4}$ não poderá seu primeiro marido, que a despediu, tornar a tomá-la para que seja sua mulher depois de contaminada; pois isso é abominável diante do Eterno, e não farás condenar a terra que o Eterno, teu Deus, te dá por herança (TORÁ, Dt 24, 1-4 p.573.).

\section{Jeremias 3,1}

Suponhamos que um homem repudie uma mulher e esta o deixe, para pertencer a outro: será que o primeiro vai querer voltar a ela? Não ficaria aquela terra irremediavelmente profanada? E tu que te prostituíste com tantos parceiros, voltarias a mim? - Oráculo do Senhor! (TEB, Jr 3,1 p.511.).

Em Ezequiel 16, podemos encontrar a reutilização midráshica de antigos materiais da história de Israel.

Êxodo 32, 2-4

${ }^{2}$ E disse-lhes Aarão: Tirai os aros de ouro das orelhas de vossas mulheres, de vossos filhos e de vossas filhas e trazei-os a mim. ${ }^{3} \mathrm{E}$ tirou todo o povo os aros de ouro de suas orelhas e os levaram a Aarão. ${ }^{4} \mathrm{E}$ tomou-os de suas mãos e os trabalhou com o buril, e fez um bezerro fundido. E disseram: Estes são teus deuses, ó Israel, os que te fizeram subir da terra do Egito (TORÁ, Ex 32, 2-4 p.259-260). 


\section{Ezequiel 16, 17-19}

${ }^{17}$ Tomaste os teus enfeites de ouro e prata, que eu te dera, e com eles fabricaste imagens de homens, com os quais te prostituíste. ${ }^{18}$ Tomaste também os teus vestidos bordados e as cobriste. Ofereceste o meu azeite e o meu incenso diante delas. ${ }^{19} \mathrm{O}$ pão que te dei - a flor de farinha --, o azeite e o mel com que te alimentei, tu os ofereceste diante delas como um perfume destinado a apaziguá-las (BSJ, Ez 16, 17-19 p.1622.).

Em outros casos, encontramos narrativas inteiras que reelaboram e adaptam narrativas anteriores. O livro de Crônicas é uma reescrita dos livros de Samuel e dos Reis, com pontos de vista diferentes. No livro de Gênesis, a nova ordem imposta após o dilúvio, reflete-se no paralelismo encontrado nas palavras de Deus dirigidas ao primeiro homem (Gn 1, 26-30) e as dirigidas à nova humanidade, Noé e seus filhos ( $\mathrm{Gn} 9,1-7)$. Contudo, entre as duas passagens bíblicas observamos significativas mudanças tais como a nova relação do homem com a criação, lei do sangue e a nova lei dietética.

Gênesis 1, 26-30

${ }^{26} \mathrm{E}$ disse Deus: "Façamos homem à nossa imagem segundo a nossa semelhança; e que domine sobre o peixe do mar e sobre a ave dos céus, e sobre o quadrúpede e em toda a terra, e em todo réptil que se arrasta sobre a terra!" ${ }^{27} E$ criou Deus o homem à sua imagem, à imagem de Deus o criou; macho e fêmea criou-os. ${ }^{28} \mathrm{E}$ abençoou-os Deus e disse-lhes Deus: "Frutificai e multiplicai, e enchei a terra e subjugai-a, e dominai sobre o peixe do mar e sobre a ave dos céus, e em todo animal que se arrasta sobre a terra". ${ }^{29} \mathrm{E}$ disse Deus: "Eis que vos tenho dado toda erva que dá semente que (se acha) sobre a face de toda a terra, e toda árvore em que há fruto de árvore que dê semente: a vós servirá para comer. ${ }^{30} \mathrm{E}$ para todo animal da terra e toda ave dos céus, e tudo o que se arrasta sobre a terra, em que haja alma viva; e toda verdura de erva (será) para comer". E foi assim (TORÁ, Gn 1, 26-30 p.3-4.). 


\section{Gênesis 9, 1-7}

${ }^{1} E$ abençoou Deus a Noé e a seus filhos, e lhes disse: "Frutificai, e multiplicai-vos e enchei a terra. ${ }^{2} \mathrm{E}$ vosso temor e vosso medo será sobre todo animal da terra, e sobre toda ave dos céus, sobre tudo o que a terra produz do que se arrasta nela, e sobre todos os peixes do mar; em vossas mãos foram entregues. ${ }^{3}$ Todo réptil que vive, a vós será para comer; (como a verdura de erva,) dei a vós tudo. ${ }^{4}$ Porém, a carne com sua alma (estando com vida) e seu sangue, não comereis. ${ }^{5}$ E por certo o vosso sangue de vossas almas requererei; da mão de todo animal a requererei; e da mão do homem; da mão do varão (que é como) seu irmão, requererei a alma do homem. ${ }^{6}$ Aquele que derrama o sangue do homem, pelo homem, seu sangue será derramado, pois à imagem de Deus fez o homem. ${ }^{7}$ E vós, frutificai, e multiplicai-vos, aumentai na terra e multiplicai-vos nela" (TORÁ, Gn 9, 1-7 p.22).

Outro ponto que destacamos são as tipologias intrabíblicas, ou a descrição de determinado personagem com características ou em contextos próprios de outro. A estrutura tipológica de um personagem é calcada em outro. Como constatamos pelas citações do livro de Gênesis acima, temos Noé como um novo Adão e também, em $J s$, Josué é apresentado como Moisés libertador; em 1 Rs 19, Elias é um novo Moisés.

Numerosos salmos e cânticos condensam em estrofes rítmicas, as extensas narrativas dos acontecimentos da salvação. O Cântico de Moisés em Ex 15 é um exemplo de desenvolvimento a partir de um antigo verso "Cantarei ao Eterno, que gloriosamente Se enalteceu; cavalo e seu cavaleiro jogou no mar" (TORÁ, Ex 15, 1 p.197), completado com estrofes que relembram os prodígios de Deus até levar o povo desde o Egito até o Monte do Templo.

Nessas releituras sapienciais destaca-se a tendência a reinterpretar as antigas tradições de Israel no livro da Sabedoria, exemplo típico são as releituras da grande aventura do êxodo e da passagem pelo deserto (Sabedoria 16-19). 


\section{Números 21, 6-9}

${ }^{6} \mathrm{E}$ enviou o Eterno para o povo as serpentes abrasadoras, e morderam o povo; e morreu muita gente de Israel. ${ }^{7} \mathrm{E}$ veio o povo a Moisés, e disse: Pecamos, porquanto falamos contra o Eterno e contra ti, ora ao Eterno para que tire de sobre nós a serpente. $\mathrm{E}$ orou Moisés pelo povo. ${ }^{8} \mathrm{E}$ disse o Eterno a Moisés: "Faze para ti uma serpente abrasadora e põe-na sobre uma haste; $\mathrm{e}$ acontecerá que todo aquele que for mordido, olhando para ela viverá". ${ }^{9} E$ fez Moisés uma serpente de cobre e a pôs sobre a haste; e eis que, se por acaso a serpente mordia a alguém, este olhava para a serpente de cobre e vivia (TORÁ, Nm 21, 6-9 p.453).

\section{Sabedoria 16, 5-12}

${ }^{5} \mathrm{E}$ mesmo quando o furor terrível dos animais venenosos desencadeou-se contra os teus, / que pereciam sob a mordida das serpentes sinuosas, tua cólera não permaneceu até o fim. ${ }^{6}$ Como advertência foram perturbados por pouco tempo, pois tinham um penhor de salvação que lhes recordava o mandamento de tua Lei. ${ }^{7} \mathrm{Com}$ efeito, todo aquele que se voltava era salvo, não pelo objeto que contemplava, / mas por ti, o Salvador de todos. ${ }^{8} \mathrm{E}$ assim provaste a nossos inimigos que és tu quem liberta de todo mal. ${ }^{9} \mathrm{~A}$ eles, mataram-nos as picadas dos gafanhotos e das moscas, / sem que se encontrasse remédio para preservar sua vida, / pois mereciam ser castigados por tais feras. ${ }^{10} \mathrm{~A}$ teus filhos, ao contrário, nem o dente das serpentes venenosas pôde vencer, pois tua misericórdia veio ao seu encontro e os curou. ${ }^{11}$ Para que se lembrassem de tuas palavras eram aguilhoados, / mas foram logo libertados / para que, tombados em esquecimento profundo, / não fossem subtraídos à tua ação benfazeja. ${ }^{12} \mathrm{E}$ não foi erva nem pomada que os remediou, / mas tua Palavra, Senhor, que a todos cura. (TEB, Sb 16, 5-12 p.1120-1121.).

Compreendemos o texto bíblico como um grande mosaico na qual as partes dialogam entre si, procurando um sentido. Esse processo de procura de compreensão e sentido do texto terá continuidade com a segunda parte do cânone judaico, denominada de 
fonte talmúdica, na qual os rabinos travam debates, comentários e criam uma hermenêutica peculiar, em particular o estilo Midrash "interpretação" explorando o texto bíblico em todas as possibilidades.

Os rabinos, estudiosos e sábios da Tradição Judaica fizeram do Tanach (Bíblia Hebraica) um laboratório de textos, impedindo seu fechamento e cuidando de preservá-lo como uma Obra aberta e com sentido para o cotidiano através das gerações.

Inferimos que o texto bíblico se transforma em linguagem e essa linguagem revela toda a dimensão da vida humana. A tentativa de perpetuar, compreender e interpretar o Pacto realizado entre Deus e os bnei Israel "Filhos de Israel" revela um estado de procura que se desenvolve e toma corpo na palavra, no ato de narrar donde, o surgimento de uma tradição oral que, posteriormente, se transforma em tradição escrita. Essa tradição escrita se divide em duas fontes básicas: a bíblica e a talmúdica, que é essencialmente um vasto campo interpretativo desenvolvido pelos rabinos, que se dedicavam a interpretar a fonte bíblica à luz de sua época.

\section{Conclusão}

Uma das características do texto bíblico é a justaposição de fontes com relatos de acontecimentos e características de uma época com os de outra. A cronologia, de modo geral, é respeitada, pois existe um sentido de fluxo de tempo histórico e das mudanças que nele ocorrem, sendo assim, não vamos encontrar Abraão como observante das leis mosaicas. Os editores que periodicamente editaram esse patrimônio literário, redigiram as fontes que tinham à sua disposição sem as nivelar completamente. Temos um texto bíblico unificado, no qual em seu interior desfilam diferentes autores em épocas diversas com aspectos linguíísticos peculiares de cada autor e período. Esse material é fruto de um longo processo de transmissão oral e posteriormente escrita, que vai sendo compilado e transmitido de geração a geração ao longo do tempo. O fechamento do cânone bíblico, em Iavné, Israel, por volta do ano 100 E.C. confere ao texto bíblico um caráter singular, na qual a história de um povo tornou-se parte de sua literatura sagrada. Com um corpus textual definido pela canonização, a leitura pública desse material e o seu trabalho de cópia e transmissão faz surgir uma nova etapa do Pacto da Memória, entrando em cena os rabinos, sábios, estudiosos da fonte bíblica que 
no intuito de continuar o dever da lembrança e procurando o sentido desse texto, geram um novo tipo de material denominado genericamente de fonte talmúdica.

O corpus talmúdico é um vasto campo de literatura rabínica que se dedica a interpretar, à luz de sua época, o texto bíblico. O texto bíblico em si mesmo não precisa de interpretação, quem procura pelo seu sentido não é o próprio texto bíblico, mas o homem dotado da capacidade de transformar em linguagem aquilo que ele interpreta desse texto. A procura de sentido do texto é uma necessidade de perpetuar o Pacto da Memória realizado entre Deus e os homens. O homem de cada tempo recebe o texto bíblico e o Pacto, e interpreta esse Pacto de acordo com os valores do interpretador (homem) e do espírito da época para que esse Pacto se perpetue com sentido através dos tempos para o homem. O que significa dizer que o judaísmo é fundamentalmente interpretação do texto bíblico, pois que este não existe sem o homem para recebê-lo e interpretá-lo.

\section{Referências}

ARANDA PÉREZ, Gonzalo et alii. Literatura judaica intertestamentária. Trad. Mário Gonçalves. São Paulo: Ave-Maria, 2000. 522 p. (Introdução ao Estudo da Bíblia, 9)

BONDER, Nilton. Rosh Ha-Shana e Iom Kipur: dias intensos. Rio de Janeiro: Imago, 1990. 132 p. (Diversos).

CLEMENTS, R.E. (org.). O mundo do Antigo Israel: perspectivas sociológicas, antropológicas e políticas. Trad. João R.Costa. Ver. Honório Dalbosco. São Paulo: Paulus, 1995. 412 p. (Bíblia e Sociologia).

FERREIRA, Cláudia Andréa Prata. Riobaldo: o indivíduo à procura da compreensão do seu Ser. Dissertação de mestrado em Ciência da Literatura - Teoria Literária. Rio de Janeiro: UFRJ, Faculdade de Letras, 1995. 124 fl. Mimeo.

FERREIRA, Cláudia Andréa Prata. $O$ pacto da memória: interpretação e identidade nas fontes bíblica e talmúdica. Tese de Doutorado em Ciência da Literatura Poética. Rio de Janeiro: UFRJ, Faculdade de Letras, 2002. 274 fl. mimeo. 
ENCICLOPÉDIA Judaica. Trad. Elias Davidovich (et al.). Rio de Janeiro: A.Koogan, 1990. 10 V.

GOTTWALD, Norman K. Introdução socioliterária à Bíblia Hebraica. Trad. A.Alvarez. São Paulo: Paulinas, 1988. 639 p. (Bíblia e sociologia).

TREBOLLE BARRERA, Julio. A Bíblia judaica e a Bíblia cristã: introdução à história da Bíblia. Trad. Ramiro Mincato. Petrópolis, RJ: Vozes, 1995. $741 \mathrm{p}$.

YERUSHALMI, Yosef Hayim. Zakhor: história judaica e memória judaica. Trad. (da 2.ed. original) Lina G. Ferreira. Rio de Janeiro: Imago, 1992. 168 p. (Bereshit).

Utilizamos para as citações bíblicas:

BÍBLIA, A. Tradução Ecumênica (TEB). São Paulo, Loyola: Paulinas. 1995. $1567 \mathrm{p}$.

BÍBLIA Sagrada de Jerusalém, A (BSJ). s.ed. São Paulo: Paulinas, 1991. $2366 \mathrm{p}$.

TORÁ. A Lei de Moisés. Edição revisada e ampliada da obra A Lei de Moisés e as Haftarót. Inclui a tradução das Cinco Meguilot por David Gorodovits e Ruben Najmanovich. São Paulo: Sefer, 2001. 685 p.

\section{Citação de datas:}

Segue a tendência internacional para pesquisas de culturas não-cristãs:
a.E.C. $($ antes da Era Comum) $=$ a.C. $($ antes de Cristo)
E.C. $($ Era Comum $)=$ d.C. $($ depois de Cristo $)$ 